

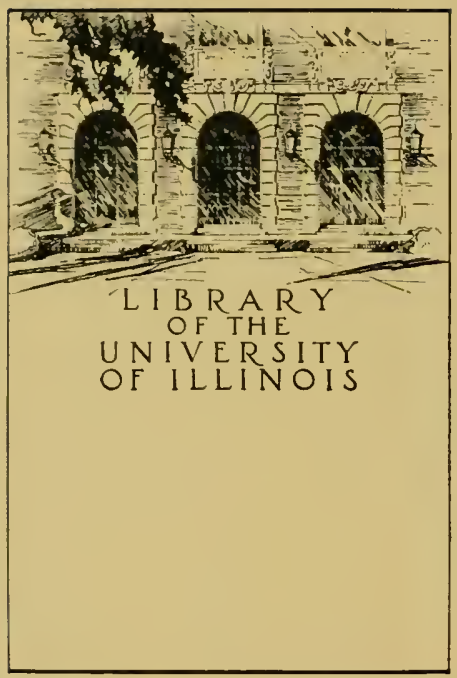




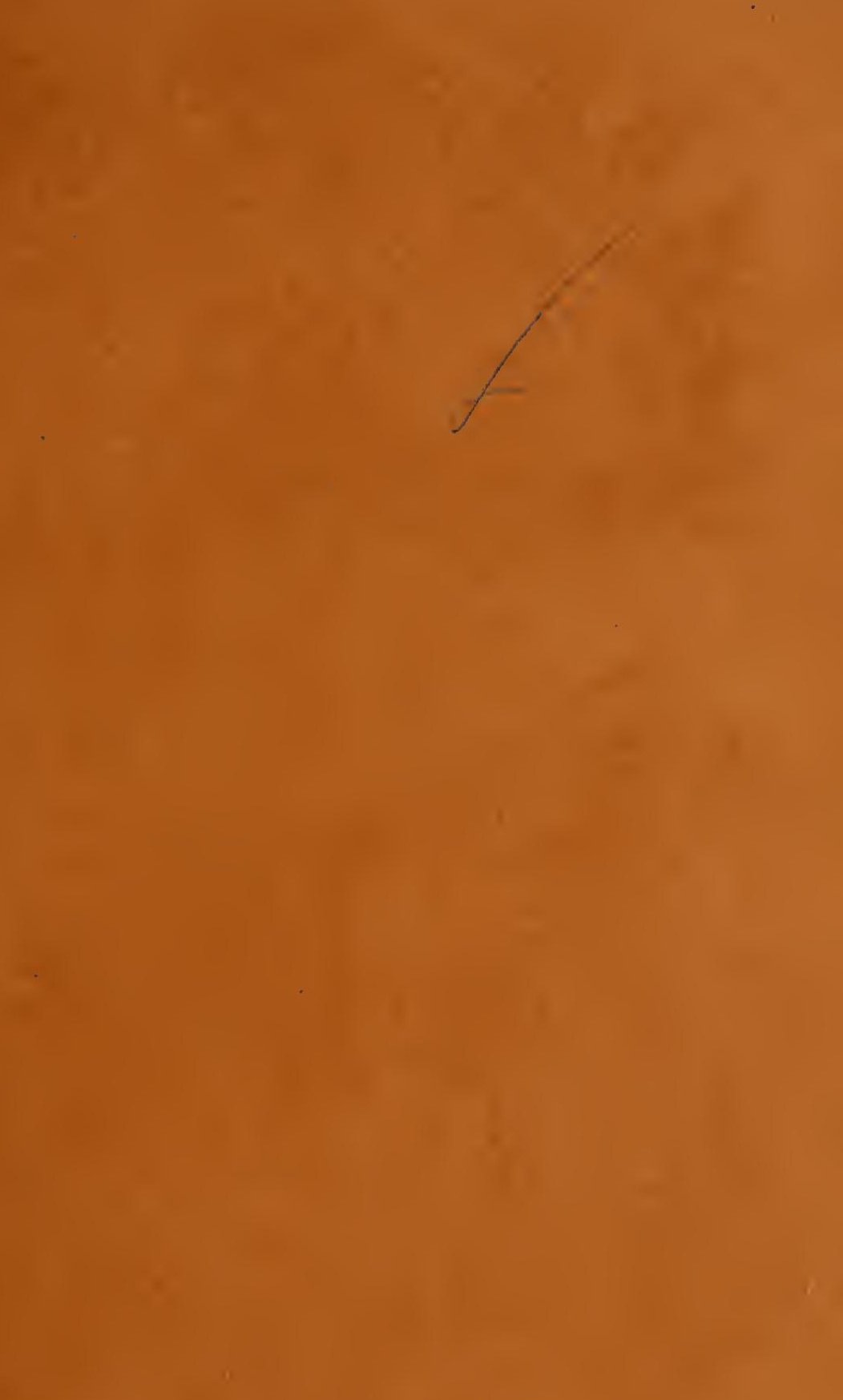





\section{PRESIDENT'S ADDRESS.}

[Reprinted from the Transactions of the Devonshire Association for the Advancement of Science, Literature, and Art. 1873.]

BEFORE entering upon the subject of my address, I am sure I shall be pardoned for referring to the tragical end of one who was the life and soul of this Association, as well as of many good and interesting works in this county. It is through his invitation, indeed, that I am here to-day, and sorely do I miss his welcome and counsel. None saw "the vain struggle, the parting agony" of that chill, autumn day, but many will long remember how the little carriage was sadly led back to the desolate parsonage, no longer to be the home of the bereaved family. He has been taken from us by that mysterious Providence which for some wise purpose cuts off so many in their career of usefulness, leaving others who might, humanly speaking, have been much better spared.

\section{"They are vanished from their place- Let their homes and hearths make moan; \\ But the rolling waters leave no trace Of pang or conflict gone."}

Varied as were Mr. Kirwan's attainments, great as was his knowledge, what groping in the dark must it all appear to him now, in the full light of truth. As the poet says:

"Death leads to the highest knowledge,

And being of all things the sole thing certain,

At least leads to the surest science."

I find myself with the task set before me of pronouncing what may be called in classical phrase a trilogy on the three great pursuits which have so long exercised enormous influence, whether for good or for ill, upon the human race. I feel deeply my incompetence to do justice to my subject, having unfortunately come into the world before it was the fashion to give so wide a scope to the education of the youthful mind. I need scarcely say that during the twelve or thirteen years passed at school and college, Science meant Plato and Aristotle; Literature was confined to the dead languages; while Art was represented, I am afraid, by cartoons which 
did not receive such encouragement from the authorities as would induce the artist to develop into a Raffaelle. I mention this in order to bespeak the indulgence of the Association, because a subsequent active life, many years of which have now been occupied in passing laws which require frequent amendment, or in endeavouring to prevent the passage of those which no amendment can improve, has not enabled me to make up for lost time. Any observations, therefore, which I can offer must be of the most ordinary and superficial character, the crude jottings of a busy man.

Science stands first on your title page. I do not quarrel with the precedence; but does not this indicate the change wrought by the last few years? When art and literature had already grown grey, science was still a little child. Was it not in the era of Milton and Vandyle that the inventor of a steam engine was consigned to a lunatic asylum for his pains?

But what is science? Science is organized knowledge, and we mean by it that which is exact in opposition to that which is speculative. Whether abstract or physical, it insists upon proof, and does not admit of faith. It believes nothing it does not understand and caunot prove. Hence science has unfortunately been ranged in antagonism to religion, and a warfare has raged, disastrous to both, which some day perhaps may be concluded by peace, and even alliance. For if certain truths we accept cannot be known without revelation, then what is rejected because contradicted by science ought probably to be received also, the contradiction being only apparent, and the agreement of the two being a matter of certainty, requiring only patience. In our present state we must be content to take much for granted. I once heard a very eminent surgeon say, "We linow by experience that certain results ordinarily follow certain treatment; but when we attempt to theorize upon this, we find our theories so constantly upset by fresh cases, that I for one have left off trying to give reasons for many of the effects produced."

\footnotetext{
"Wait, nor against the half-learned lesson fret, Nor chide at old belief as if it erred,

Because thou canst not reconcile as yet

The worker and the word."
}

An old divine said well, "We have much enquiry after knowledge in these latter times. The sons of Adam are now as busy as ever himself was about the tree of knowledge of good and evil, shaking the boughs of it, and scrambling for the fruit." Those who are weak and wavering, and those 
who have an interest in maintaining things as they are, naturally view the bold attacks of scientific men on their fortress with alarm. They see the plaster with which the misplaced labour of generations has coated the walls crumble under the fire of the enemy, without perceiving that, when this is swept away, but little impression will have been made on the solid structure. Galileo was imprisoned, not because the authorities of the Inquisition cared whether the sun or the earth moved, but because they dreaded the spirit of enquiry. The opinion, however, is gaining ground that God's truth cannot suffer by the extension of man's truth. We may, indeed, enquire diligently what is the truth; but it argues a very weak faith to suppress enquiry because it may militate against what we may have been in the labit of regarding as the truth. The Roman Proconsul, when told that the Christians were destroying a temple, merely replied, "Let the gods defend themselves." There was deep meaning in the answer. I for one have no fear of the result; but much harm may be done by misguided zeal. The assailants are men of world-wide reputation, giants in intellect, and their arguments cannot be confuted by mere generalities or platitudes. Those who enter the lists should be well acquainted with the turns and changes of the contest, and the way in which new ground has been taken from time to time; and they should especially be well versed in the language of the books under review. Even educated Hindoos have lately been accusing our divines of condemning their sacred books without being able to read them. Nothing is easier than to pour out indignation against setters forth of strange doctrines, and to demolish them amidst the cheers of an unanimons meeting; but weapons of a far different temper and calibre are required in a contest with such antagonists. It was once said at a trial, "I thought the defendant's case massailable till I heard his counsel's speech."

So much for the polemical literature of science. But science is the handmaid of art; and in those branches of art which may be termed useful or mechanical, what strides have been made since Archimedes invented the lever, and, with that conficlence which has descended to his snccessors, declared that he would move the world. They have been moving the world ever since. Nothing seems too hard or too daring for our engineers. We often hear in their evidence before parliamentary committees that nothing is impossible ; it is only a question of expense. And when we contemplate what has been done within our urn recollection, we must 
admit that there is justification for their boldest plans. I once heard the late Lord Derby say that he was on the committee which threw out the first railway bill, on the ground that a speed of more than twelve miles an hour would be dangerous to human life. Lord Derby was still a young man when Brunel travelled from Bristol to London, one hundred and twenty miles, considerably within two hours! We have put a girdle of telegraphic wire round the world. A toast has been given from London to Calcutta, and the reply received, within the space of an ordinary banquet. Going westward, our statesmen's speeches are read in New York apparently before they are delivered in London. ITe build our war ships of enormous masses of iron, and arm them with guns, each one more formidable than a broadside of the last generation. Vessels have been invented which, like tish, cans wim either upon or below the surface. Bridges, no longer supported on arches or by chains, are level iron roads, striding across broad rivers and arms of the sea. Railway trains climb a mountain seven thousand feet high, while others run seven miles through its centre; and we are threatened this summer with a friendly invasion from America by balloon. The predictions of Darwin in the Botanic Garden were deemed in his day as extravagant as his grandson's theories are by most people now. But time has justified them. Writing many years before steam vessels, railways, or torpedo ships, he says:

\footnotetext{
"Soon shall thy arm, unconquered steam, afar Drag the slow barge, or drive the rapid car; Or, on wide waving wings expanded, bear The flying chariots through the fields of air.'Taught by the sage, lo! Britain's sons shall guide Hugb sea-balloons beneath the tossing tide."
}

These are great achievements; but machinery is like the trunk of an elephant, which can not only uproot a tree, but pick up a pin. The art of saving labour by mechauical contrivances is yet in its infancy. It will be a vast addition to human happiness, a great blessing to employers and employed, when the labour which is only worth starving wages shall be everywhere performed by machinery.

Architecture forms a connecting link between the mechanical and the tine arts. Some wag has suggested that we shall have no success in architecture till we have hanged an architect; and, indeed, we have little to boast of in these degenerate days. Our churches built during the last twenty-five years are doubtless superior to those of the preceding century, but simply because we have reverted to earlier models. In London, 
Somerset House and Waterloo Bridge are almost the only civil structures which excite the admiration of foreigners. Some of the clubs are worthy of notice, especially for the excellence of their arrangements, in all respects except ventilation, an appliance yet to be discovered in northern latitudes. The House of Parliament is a gigantic and most costly failure. It seems to have been designed with little regard to the purpose it was to serve. The arrangements for enabling even niembers of the Government to transact that large part of the business of the country which is carried on by means of personal interviews are still far inferior to those of any House of Assembly I have ever seen, though improvements have been made by frequent alterations. In private houses there has been a marked advance in convenience, and in sanitary appliances. In towns we no longer bury our basements in Cimmerian darkness, nor erect dead walls before our attics. In the country we do not so generally destroy the health and light of our offices and stables by planting masses of shrubs close to the windows. Common sense has banished spurions taste. Genuineness and reality are at length driving out sham and stucco. We are still, however, inclined to copy defects which were caused by poverty of material in early styles; to narrow our windows, though we have glass in abundance; and to give our roofs an excessive pitch, though no longer obliged to load them with enormous weights. At the same time we have venturer on daring inmovations by land, as well as in naval architecture, and the mode in which glass and iron were employed in the Exhibition of 1851 has been widely copied.

In architecture, and still more in the fine arts, though there are certain canons which have always been recognized, yet taste has varied from age to age under the guidance generally of some one who has either from his power of explaining and enforeing his views, from lis position, or some other cause, been looked up to as an authority. But whereas in science we boast of our superiority to those who have preceded us, having the advantage of their accumulated stores of experience, the case is different in regard to literature and the fine arts. In these excellence springs forth, like Minerva, full-grown, and especially during the youth of the worlı. Poetry is the earliest language of a race, and we are, I think, justified in saying that nations, like individuals, may write thermselves out. Certainly in the earlier authors we find more vigorous and condensed thought, more expressions that have become, as it were, current coin, than in those of later date. It must, however, be admitted that stirringsevents and organic changes, social or 
political, may give new subject-matter and fresh impetus to contemporary literature. The treasures of ancient Greece in the galleries of Rome and Florence excite the admiration and despair of modern sculptors. Excavations in Pompeii and elsewhere have proved that while the art of painting was not inferior, the secret of preserving paintings was understood in a still more remarkable manner. In the museum of Cortona is a female head in the highest style of art. It was dug up by a peasant from the bottom of a ditch where it had probably lain for fifteen hundred years, was by him used as a shutter, and exposed to the sun by day and the frost by night, and yet appears now as perfect as when fresh from the painter's hand. It is on slate, and has been by some unknown process rendered practically indestructible.

Those who presume to dogmatize on painting or sculpture are on very delicate ground. We all remember the secret for acquiring the reputation of a cognoscento in the Vicar of Wakefield, which "consisted in a strict adherence to two rules, the one always to observe the picture might have been better if the painter had taken more pains, and the other to praise the works of Pietro Perugino." The price which collections of acknowledged excellence command proves the value set upon the judgment of others by persons who mistrust their own. How few can see any merit in a work without a character is shown by the case of Lord Suffolk's stolen pictures, and the famous Guido of San Bartolomeo in Bologna, which were long exposed, and eventually sold for a trifle in IVardour Street, no one having been attracted, except those by whom the pictures were recognized. So again, in the well-known instance of the buried statue of Bacchus, praise which had been withheld from the work of Michael Angelo, was lavishly bestowed by the connoisseurs of Florence upon the supposed antique. The Greeks and Romans seem scarcely to have appreciated scenery for its own sake, though the similes of Homer, the pastorals of Theocritus, passages like the apostrophe to the Clouds in Aristophanes, the description of rural retreats in Horace, show that they were not unobservant of nature. Where cities are few, and the country wild and uncultivated, full of danger and hardship to the wayfarer, and perhaps peopled by superstition with malignant beings, the lonely settler looks with repugnance upon the "savage mountain," the "brown horror of the wood." Hence the best descriptions of scenery have been written by dwellers in cities. On the other hand, when population increases, when towns swallow ul) green fields, and the sea coast becomes 
almost a continuous terrace, we cling to what remains of rural scenery. Our writers enlarge upon it in prose and verse, and our painters transfer to their canvas the hayfield, the sandy nook, the quiet corner of the wood. It would be invidious to mention names, but we must all agree that descriptions of country in prose and verse, as well as delineations of country in oils and water-colours, in our own day and our own land, will bear comparison with those of any nation or of any age. There is one characteristic which specially marks the modern English school of painting, namely, extreme accuracy. IVe know that some artists make it a point of conscience to leave nothing to memory, to fill in every line aud every tint from nature, and we value them accordingly. Perhaps we owe this in part to photography, which is a terrible witness against a slovenly or too imaginative artist, as far as outline is concerned, and partly to the præ-Raffaelite school, which has carried on a successful warfare against conventionality. As in reforms of other kinds, the reformers liave probably gone too far, justice without mercy is not desirable even in a portrait. Some one has said nothing is so false as a fact, and it is surely a mistake to paint as if man had "a microscopic eye," and could distinguish "each particular hair" upon a caterpillar several yards off. As an exact illustration of my meaning, I may instance a very clever picture in the Royal Academy some years ago. It was a small patch of wheatfield. The spiky ears, blue cornflowers, and twining convolvuli, the shiny beetles, and glittering dewdrops, were painted with marvellous accuracy and minuteness. And then the artist, apparently struck with the conviction that no mortal eye could have taken it all in, gave his picture the "grace of congrnity" by placing the scene in Brobdignag, with Gulliver gazing upon the gigantic growth from a furrow as high as his shoulders. As neither art nor literature are ashamed of the homely joys and sorrows of daily life, so are they more and more appreciated by the general public. No longer has the artist or author to languish in the ante-rooms of the great. The great come to him, and the small too, and the latter are from their numbers no contemptible patrons; but as in former times the pen and pencil were too often the humble servants of powerful vice, and even the basis of history was less fact than faction, so in these latter dlays there is danger of pandering not to the single patron, but to the multitude. The leading press of this country bears a deservedly high character. Its colmmns are full of most valuable matter, and I believe its conductors honestly cndeavour to instruct as well as to attract 
their readers. But it is not universally so. The editor of an American paper was once taken to task on account of a violent anti-English article, and he was asked whether those were his real sentiments. "No," replied he, "but my paper costs a cent. I leave you to calculate how many subscribers I must have to enable me to live. If I don't print what they like, they wont buy the paper."

We must not be ungrateful to periodical literature, which adds so much to our enjoyment, and has given a first start to so many able writers; but it somewhat encourages the tendency to write for the present, and not for all time. The difference between the two classes is well explained by Alfred de Vigny, in Cinq Mars: "Les uns etaient des hommes obscurs, fort illustres à présent. Les autres des hommes illustres, fort obscurs pour nous-posterité."

It has been said that a well known poet suffered agonies of self-reproach from the fear that even his remote descendants might be injured by reading his works. And truly some of our sensational novelists have much to answer for. Those I mean whose heroes possess the proverbial qualifications for mundane happiness, a good digestion, and no conscience. Guardsmen of a type, we may believe, little known in the Household Brigade, who "spare no man in their anger and no woman in their licentiousness;" and, after a career of unmitigated villainy, settle down in patriarchal peace and respectability. It is no light thing to invest such characters with the halo of romance. IVe are but too inclined to sympathize with reckless lawlessness. Has not some one said that the most interesting character in Paradise Lost is Satan? But there are lower depths still. Scandalous publications, striking at law and order through religion, of which the Moderator of the General Assembly of Scotland has lately spoken with becoming indignation. He calls them "infidel and impure literature." But I will not so degrade the uame. They bear the same relation to literature that poison does to food, and those who disseminate them are even worse than the wretches who carried about infected straw for the purpose of spreading the cattle-plague.

To revert for one moment to the fine arts. Is there not some danger that the patronage of the million may, while increasing the quantity, somewhat lower the quality? Will not the composer produce "tunes which jingle well"? and the artist paint down to art union prizes? Moreover there is that in the relations between artists and certain London dealers, to which I need only allude, but which, if not promptly stamped 
out, will do more to destroy the self-respect and independence of the profession than all the patrons of the Georgian era.

The effect of more extended appreciation upon art and literature brings us to the effect of science, literature, and art upon the million. A man with his bread to earu must necessarily regard the occupation of his life from an utilitarian point of view. Time has to him an actual money value. Now, in my humble opinion, too much has been said about certain studies improving and strengthening the mind rather than other's. Surely this depends more upon the mode of teaching than upon the subject taught. Picking up a modern langrage by ear does not exercise the meutal powers like the careful study of a dead language. But why should not the one be as carefully taught as the other? I do not believe in the "conflict of sturlies" in this sense. Icliots may possess great aptitude for calculation and for music; but it does not follow that the study of mathematics or music may not strengthen the powers even of a powerful mind. So the various arts and sciences, applicable to industry, may be taught in a manner to develop the faculties. "Life," as Sydney Smith says, "has been distressingly abridged since the Hood." And if the mind can be nourished by the same food with which the boly is fed, what an economy is effected! A blacksmith requires a strong arm. Rowing strengthens the arm; but it would be a palpable fallacy to say, therefore, a blacksinith should be taught to row instead of to wield the hammer. And though an educated man may have the power of learning something for which people will pay sooner than if his mind had lain entirely fallow, yet there is a risk that the steed may starve while the grass is growing. A French periodical, the Echo Agricole, complaining of the useless system of schools, asks "why the mind should be led throngh delusive labyrinths instead of being drawn to the observation of natural phenomena, whence it would bring to other branches of knowledge the spirit of methodical order, which it would have been obliged to employ in the stndy of nature. There should be introduced," continues the writer, "into primary schools the elementary teaching af natural science applied to what children see daily in the comtry." Such a system as this, by which the foundation would be laid for technical education, might well be adopted in the elementary schools of this country, which keep too much to the old groove, exercising the memory instead of the mind, and producing conceited prigs, who despise the honest calling of their parents, and are unit for any other. 
It is refreshing to turn to the last Report of the Science and Art Department, just issued, which I commend to the study of all who take an interest in real education as distinguished from mere cran. Having already exceeded my limit, I can do no more than glance at the various subjects in which examinations have been held, merely premising that besides grants from Government there are prizes for practical work founded by private benefactors, among whom I may mention Sir Joseph Whitworth, of Manchester, and the Plasterer's' Company, who have revived the original intention of the great city guilds, namely, the improvement of the trades with which they are commecter. In the science branch papers have been worked in geometry, in the construction of machines, buildings, and ships; in mathematics and mechanics, in aconstics, on light, lieat, magnetism, and electricity; in chemistry, geology, mining, mineralogy, and metallurgy; in zoology, economic botany, in navigation, on steam, and in physical geouraphy. In the art branch aid is given to drawing in elementary and night schools, "where specially directed to the improvement of the perceptive powers of the children." Grants are also made to more advanced schools, in which the student pursues the technical study of art in the direction required by his occupation. In both branches assistance is given towards the training of competent teachers. I am glad to say that the payment of fees is considered essential to the maintenance of a proper system of instruction. People rarely value what they get for nothing, and the artizan classes are, generally speaking, well able to pay for the improvement of themselves and of their children.

We are at this moment in a transition state: old things are passing away, all things are becoming new. The skilled artizan can now obtain a far larger income than at any former jeriod. Like other people who have come suddenly into fortumes, he sometimes makes a queer use of it. The inmense increase in the spirit duties, among other things, shows that much of this wealth is squandered in sensual and brutalizing pleasures; but let us not forget that such were the pleasures of classes much above them less than a century ago. And what has to a great degree weanerl those classes from such pleasures? Surely the superior attraction of those pursuits for the advancement of which this Association was formerl. A nation camnot be civilized by Act of larliament any more than it can be dragooned into religion. Both plans have been tried, and both have failed. But as the streamlets pierce our red cliffs, and bring them down piecemeal year after year, so 
will the streams of knowledge gradually and silently make their way through the stubborn barrier of ignorance and vice. The report of the Science and Art department speaks of a sensible improvement in the work, and of increasing numbers of students. True, they are as yet mere drops, but they may be the first drops of a shower. Even if generations should pass before the masses are civilized, as generations have passed in the case of those above them, what are a few generations in the life of a nation, when we consider the end to be attained? We must have patience, and not, as is our habit in these restless times, be perpetually digging up our seed, in order to see whether it is growing. We can but plant and water for a little while before we pass away, lut if we do our lart we shall pass away in the full assurance that our successors will reap the fruit of the tree we have plantecl. 



